\title{
URGENSI PERAN SERTA MASYARAKAT DALAM UPAYA PENCEGAHAN DAN PEMBERANTASAN TINDAK PIDANA KORUPSI
}

\author{
Marten Bunga ${ }^{1}$, Mustating Dg Maroa², Amelia Arief ${ }^{3}$ Hardianto Djanggih4* \\ 1 Fakultas Hukum, Universitas Gorontalo \\ 2Fakultas Hukum, Universitas Muhammadiyah Luwuk Banggai \\ 3Sekolah Tinggi IImu Sosial \& IImu Politik (STISIP) 17-8-1945 Makassar \\ 4Fakultas Hukum, Universitas Tompotika Luwuk Banggai \\ hardianto.djanggih@gmail.com
}

\begin{abstract}
Corruption crimes have caused destruction to the nation's economy. This article aims to examine the role of the community in efforts to prevent and eradicate corruption. The research method in this article is normative legal research that is prescriptive analytical, through conceptual approach, statute approach, and case approach. The results of the study concluded that: first, the role of the community must participate in efforts to prevent and eradicate corruption in the grounds that the community is a victim and the community as a component of the state. Second, the form of community participation in the prevention and eradication of criminal acts of corruption is to follow the provisions of community participation as regulated by legislation by carrying out planned and unplanned social controls to educate, invite or even force citizens to adjust yourself with the habits and life values of the people concerned.
\end{abstract}

Keywords: Role; Society; Eradication; Corruption.

\begin{abstract}
ABSTRAK
Kejahatan Korupsi telah mengakibatkan kehancuran bagi perekonomian bangsa. Artikel ini bertujuan untuk mengkaji peran serta masyarakat dalam upaya pencegahan dan pemberantasan Tindak Pidana Korupsi. Metode penelitian dalam artikel ini adalah penelitian hukum normatif yang bersifat preskriptif analitis, melalui conceptual approach, statute approach, dan case approach. Hasil penelitian menyimpulkan bahwa : pertama, peran masyarakat harus turut serta dalam upaya pencegahan dan pemberantasan tindak pidana korupsi dengan alasan bahwa masyarakat sebagai korban dan masyarakat sebagai komponen negara. Kedua, bentuk peran serta masyarakat dalam upaya pencegahan dan pemberantasan tindak pidana koruosi adalah dengan mempedomani ketentuan peran serta masyasrakat sebagaimana telah diatur pada perundang-undnagan dengan melakukan kontrol sosial yang direncanakan maupun yang tidak direncanakan untuk mendidik, mengajak atau bahkan memaksa para warga masyarakat agar menyesuaikan diri dengan kebiasaan dan nilai kehidupan masyarakat yang bersangkutan.
\end{abstract}

Kata Kunci: Peran; Masyarakat; Pemberantasan; Korupsi.

\footnotetext{
* Corresponding Author
} 


\section{A. PENDAHULUAN}

Proses pembangunan saat ini dapat menimbulkan dampak positif dari berbagai bidang, baik infrastruktur, ekonomi maupun di dalam kehidupan masyarakat. Selain itu juga mengakibatkan perubahan kondisi sosial masyarakat yang memiliki dampak sosial negatif seperti tindak pidana yang sangat meresahkan masyarakat (Putriyana \& Puspita, 2014). Tindak pidana di sini yang dapat merugikan keuangan negara, perekonomian melemah, dan mencegah pembangunan nasional. Tindak pidana yang dimaksud itu cukup fenomena dan banyak dibicarakan di media cetak, elektronik dan sebagainya yakni Kejahatan Korupsi.

Kejahatan korupsi merupakan fenomena sosial yang masih sulit dalam pemberantasannya karena sudah menjadi budaya (Sulastri, 2012). Efek kejahatan korupsi telah mengakibatkan kehancuran bagi ekonomi bangsa. Dengan adanya korupsi pembangunan dalam segala bidang tidak berjalan secara baik. Kejahatan korupsi telah menjadi gurita yang mensengsarakan rakyat Indonesia (Basri 2017). Oleh karena itu, Tindak Pidana Korupsi merupakan masalah serius, tindak pidana ini dapat membahayakan stabilitas dan keamanan masyarakat, membahayakan pembangunan sosial ekonomi dan juga politik serta dapat merusak nilainilai demokrasi dan moralitas karena lambat laun perbuatan ini seakan menjadi budaya (Sukmareni, 2018).
Korupsi yang terjadi di Indonesia pada saat sekarang bukanlah suatu korupsi yang terjadi secara kebetulan dalam pengelolaan uang negara oleh oknum - oknum penyelenggaraan negara I instansi Pemerintah / Badan Usaha Milik Negara (BUMN) maupun Badan Usaha Milik Daerah (BUMD), tetapi adalah suatu korupsi yang sudah terencana atau direncanakan dengan matang jauhjauh hari pada tahap proses perencanaan maupun awal pelaksanaan anggaran. Sudah sejak dekade tahun delapan puluhan begawan ekonomi kita, Prof. Sumitro Djojohadikusumo mengatakan bahwa tingkat kebocoran dalam pengelolaan keuangan negara mencapai tiga puluh persen. Kebocoran yang tinggi tersebut terus berlangsung sampai saat sekarang (Surachmin, \& Cahaya, 2013).

Perkembangan kejahatan korupsi di Indonesia masih tergolong tinggi, sementara pemberantasannya masih sangat lamban (Ridwan, 2012). Hal ini disebabkan oleh pemerintah seakan kehilangan fungsinya untuk mengatasi para pelaku tindak pidana korupsi. Pemerintah tidak mampu mengatasi permasalahan yang terjadi. Hukum seakan lemah dalam menangani masalah padahal sudah diketahui bahwa korupsi sangat merugikan bangsa dan negara (Hamzah, 1999).

Upaya untuk mencegah terjadinya korupsi, dilakukan dengan berbagai tindakan yang tetap merujuk pada ketentuan yang berlaku. Disamping itu pemberantasan praktek korupsi diusahakan tidak terjebak dalam pembenaran terhadap korupsi sekecil apapun dengan dalih harmonisasi 
kehidupan masyarakat dan pola pikir integralistik yang menafikan pelanggaran, dengan mengaitkan pada nilai budaya serta pola pikir paternalistik lain yang menafikan penyelewengan yang dilakukan oleh mereka yang memiliki kekuasaan. Upaya untuk memberikan penyadaran terhadap masalah korupsi harus melibatkan peran serta masyarakat. Sesuai dengan amanah Undang-undang No. 31 Tahun 1999 jo Undang-Undang No. 20 Tahun 2001 tentang Pemberantasan Tindak Pidana Korupsi. Di mana pada pasal 41 menyebutkan bahwa masyarakat dapat berperan serta membantu upaya pencegahan dan pemberantasan tindak pidana korupsi.

Penelitian sebelumnya terkait subtansi pencegahan dan pemberantasan Tindak Pidana Korupsi belum dilakukan, I Made Walesa Putera dkk (2018) membahas arti pentingnya mencegah tindak pidana korupsi dalam pengelolaan keuangan dana desa serta peran serta masyarakat dalam Pencegahan Tindak Pidana Korupsi pengelolaan keuangan dana desa. RB. Soemanto, Sudarto dan Sudarsana membahas tentang pemahaman masyarakat tentang korupsi (2017). Peran Lembaga Swadaya Masyarakat (LSM) sebagai kekuatan pengimbang, pemberdaya masyarakat, dan sebagai lembaga perantara memiliki peranan di dalam bidang pencegahan, pengendalian, dan penanganan kasus korupsi di Kota Samarinda (Sumarni 2015). Ketidakmampuan LSM antikorupsi memberikan kontribusi yang signifikan dalam memberantas korupsi, dan membangun model pemberdayaan LSM antikorupsi yang efektif sehingga selanjutnya berkontribusi signifikan dalam memerangi korupsi (Machfud, 2017). Penelitian tentang perlunya model pendidikan anti korupsi menyangkut perspektif mentalitas budaya dan pembentukan perilaku anti-korupsi di masyarakat kita (Santoso, \& Meyrasyawati. 2015). Penelitian yang lain membahas tentang peran lembaga pendidikan dalam pemberantasan Tindak Pidana Korupsi di Indonesia (Ridwan. 2012). mengapa LSM antikorupsi belum mampu memberikan kontribusi yang signifikan dalam memberantas korupsi, dan (ii) bagaimana model pemberdayaan LSM antikorupsi yang efektif sehingga selanjutnya berkontribusi signifikan dalam memerangi korupsi

Minimnya perhatian dan kajian terhadap peran partisipasi masyarakat maupun akuntabilitas publik dalam upaya pemberantasan korupsi telah memberikan dampak terhadap kualitas yang tidak memadai dari partisipasi masyarakat itu sendiri (Kurniawan, 2009). Oleh sebab itu perlu ditumbuhkan kesadaran bagi setiap warga negara bahwa melaporkan sesuatu korupsi, merupakan perbuatan berpahala karena dapat membantu memberantas korupsi. Sebagaimana dijelaskan bahwa masyarakat diberi hak untuk membantu pemerintah untuk mencari, memperoleh dan memberikan informasi adanya dugaan telah terjadi Tindak Pidana Korupsi dan hak menyampaikan saran dan pendapat secara bertanggung jawab 
kepada penegak hukum yang menangani perkara Tindak Pidana Korupsi.

Pada saat ini masyarakat cenderung bersikap diam terhadap perbuatan korupsi. Selain akan merepotkannya, juga dengan pertimbangan bahwa laporan tersebut tidak akan ditanggapi dengan jujur. Selama masyarakat beranggapan demikian maka akan sangat sulit mengharapkan perilaku masyarakat yang membantu untuk mencegah/memberantas korupsi.

\section{B. METODE PENELITIAN}

Jenis penelitian merupakan kajian hukum normatif yang bersifat preskriptif analitis, melalui conceptual approach, statute approach, dan case approach dalam mengkaji peran serta masyarakat dalam upaya pencegahan tindak pidana korupsi. Conceptual approach digunakan untuk membandingkan dan menganalisis konsep penyalahgunaan wewenang dan konsep peran serta masyarakat dalam upaya pencegahan tindak pidana korupsi. Statute approach diperlukan untuk mengkaji pengaturan mekanisme peran serta masuarakat dalam upaya pencegahan tindak pidana korupsi. Kemudian case approach untuk melihat penggunaan istilah peran serta masyarakat dalam upaya pencegahan tindak pidana korupsi. Sumber data dalam penelitian ini terdiri dari data sekunder, yang berupa bahan hukum primer, sekunder, dan tersier. Data yang terkumpul dianalisis secara deskriptif kualitatif. Analisis dilakukan secara kualitatif, baik dengan mengedepankan prinsip-prinsip hukum maupun menganalisis factor-faktor lain yang mempengaruhi substansi dan prosedural penyelesaian kasus tanah.

\section{HASIL DAN PEMBAHASAN}

\section{Urgensi Peran Serta Masyarakat Dalam Pencegahan \& Pemberantasan Tindak Pidana Korupsi}

Kejahatan korupsi di Indonesia sampai saat ini masih sangat memprihatinkan, karena hampir setiap lembaga atau institusi masih terjadi praktikpraktik korupsi (Rohrohmana, 2017). Kejahatan korupsi terjadi bukan hanya terjadi di Indonesia, tetapi juga di seluruh dunia. $\mathrm{Hal}$ tersebut sebagaimana tercantum dalam preambul ke-4 United Nations Convention Againts Corruption, tahun 2003 yang menyatakan: "meyakini bahwa korupsi tidak lagi merupakan masalah lokal, melainkan suatu fenomena transnasional yang mempengaruhi seluruh masyarakat dan ekonomi yang mendorong kerja sama internasional untuk mencegah dan mengontrolnya secara esensial (Widyastuti, 2015).

Semua negara di dunia sepakat bahwa kejahatan korupsi nmerupakan bentuk kejahatan yang dapat dikategorikan sebagai tindak pidana "luar biasa". Disebut luar biasa karena umumnya dikerjakan secara sistematis, punya aktor intelektual, melibatkan stakeholder di suatu daerah, termasuk melibatkan aparat penegak hukum, dan punya dampak "merusak" dalam spektrum yang 
luas (Thalib, Ramadhan, \& Djanggih, 2017). Karakteristik inilah yang menjadikan pemberantasan korupsi semakin sulit jika hanya mengandalkan aparat penegak hukum biasa, terlebih jika korupsi sudah membudaya dan menjangkiti seluruh aspek dan lapisan masyarakat (Pohan, 2014). Oleh karena itu, Operasionalisasi pemberantasan korupsi harus dilakukan secara komprehensif, integral, dan holistik (Waluyo, 2014).

Permasalahan memerangi tindak pidana korupsi memang selalu saja harus dikembangkan, karena ternyata angka korupsi selalu saja meningkat demikian juga dengan modus yang dilakukannya (Garnasih, 2009). Dalam upaya pencegahan dan pemberantasan Tindak Pidana Korupsi, sering kali masyarakat hanya membebankan tugas tersebut kepada Komisi Pemberantasan Korupsi (KPK) dan/atau kepada para penegak hukum lainnya. Sedangkan didalam konstitusi negara ini menyebutkan bahwa masyarakat harus ikut andil dalam menangani Tindak Pidana Korupsi tersebut dalam arti lain masyarakat berperan serta dalam upaya pencegahan dan pemberantasan Tindak Pidana Korupsi.

Di Negara Indonesia menganut sistem pemerintahan yang demokrasi. Sesuai dengan prinsip-prinsip sistem pemerintahan demokrasi tersebut maka peran serta masyarakat sangat penting dalam pemberantasan korupsi di negara ini. Peran serta masyarakat yang dimaksud adalah peran aktif masyarakat untuk mewujudkan penyelenggaraan negara yang bersih dan bebas dari korupsi, kolusi dan nepotisme yang dilaksanakan dengan mentaati hukum, moral dan sosial yang berlaku dalam lingkungan masyarakat, berbangsa dan bernegara. serta dapat diwujudkan dalam bentuk antara lain mencari, memperoleh, memberikan data, atau informasi tentang Tindak Pidana Korupsi dan hak menyampaikan saran, pendapat dan bertanggung jawab terhadap pencegahan dan pemberantasan Tindak Pidana Korupsi.

Berdasarkan Undang-Undang Nomor 30 Tahun 2002 Tentang Komisi Pemberantasan Tindak Pidana Korupsi, bahwa Pemberantasan Tindak Pidana Korupsi dirumuskan sebagai serangkaian tindakan untuk mencegah dan memberantas Tindak Pidana Korupsi melalui upaya koordinasi, supervisi, monitor, penyelidikan, penyidikan, penuntutan dan pemeriksaan di sidang pengadilan dengan peran serta masyarakat berdasarkan peraturan perundang-undangan yang berlaku. Rumusan Undang-Undang tersebut menyiratkan bahwa upaya pemberantasan tindak pidana korupsi tidak akan pernah berhasil tanpa melibatkan peran serta masyarakat. Dengan demikian, dalam strategi pemberantasan Tindak Pidana Korupsi terdapat tiga unsur utama yaitu pencegahan, penindakan dan peran serta masyarakat (Nugraheni, 2017).

Pencegahan adalah seluruh upaya yang dilakukan untuk mencegah terjadinya perilaku koruptif. Pencegahan juga sering disebut dengan 
kegiatan anti korupsi yang sifatnya preventif. Penindakan adalah seluruh upaya yang dilakukan untuk menanggulangi atau memberantas terjadinya Tindak Pidana Korupsi. Penindakan juga disebut sebagai kegiatan kontra korupsi yang sifatnya represif. sedangkan peran serta masyarakat adalah peran aktif perorangan, organisasi masyarakat atau Lembaga Swadaya Masyarakat dalam pencegahan dan pemberantasan Tindak Pidana Korupsi (Nugraheni, 2017).

Dalam hal Peran masyarakat disini sangat diperlukan dalam pemberantasan Tindak Pidana Korupsi. Paling tidak, masyarakat harus ikut ambil bagian karena dua hal yakni masyarakat sebagai korban dan masyarakat sebagai komponen negara. Ditinjau dari masyarakat sebagai komponen negara bahwa suatu negara terdiri atas tiga komponen utama yaitu Pemerintah, Masyarakat dan Swasta. Keberhasilan suatu negara sangat tergantung pada kinerja dan kerja sama ketiganya jika kerja sama dilakukan dengan baik maka akan berpengaruh baik pada negara ini, begitupun sebaliknya jika buruk cepat lambatnya bangsa itu akan hancur (Matodang, 2012).

Tentu bukan hal yang mudah dalam memecahkan masalah korupsi, sekalipun harus melibatkan seluruh elemen bangsa termasuk rakyat, hal ini karena korupsi merupakan kejahatan yang dinamakan dengan White Collar Crime (Sutedi, 2015) serta sebagai kejahatan luar biasa (Extra Ordinary Crime).

\section{Bentuk Peran Serta Masyarakat dalam Pencegahan \& Pemberantasan Tindak Pidana Korupsi}

Dasar hukum bagi masyarakat untuk dapat berperan serta dalam pencegahan dan pemberantasan Tindak Pidana Korupsi sebenarnya sudah diatur di dalam pasal 108 ayat 1 dan ayat 3 Undang-Undang Nomor 8 Tahun 1981 Tentang Kitab Undang-Undnag Hukum Acara Pidana (KUHP), yaitu: (1) Setiap orang yang mengalami, melihat, menyaksikan dan atau menjadi korban peristiwa yang merupakan tindak pidana berhak untuk mengajukan laporan atau pengaduan kepada penyidik dan atau penyidik, baik lisan maupun tertulis; (2) Setiap pegawai negeri dalam rangka melaksanakan tugasnya yang mengetahui tentang terjadinya peristiwa yang merupakan tindak pidana wajib segera melaporkan hal itu kepada penyelidik atau penyidik.

Peran serta masyarakat dalam pencegahan dan pemberantasan Tindak Pidana Korupsi tambah semakin jelas lagi berdasarkan ketentuan Undangundang No. 31 Tahun 1999 jo Undang-Undang No. 20 Tahun 2001 tentang Pemberantasan Tindak Pidana Korupsi pada pasal 41 ayat 2 disebutkan bahwa peran serta masyarakat dalam pemberantasan Tindak Pidana Korupsi dapat diwujudkan dalam bentuk: (a) Hak untuk mencari, memperoleh dan memberikan informasi adanya dugaan telah terjadi Tindak Pidana Korupsi; (b) Hak untuk memperoleh pelayanan dalam mencari, memperoleh dan memberikan informasi adanya 
dugaan telah terjadi Tindak Pidana Korupsi kepada penegak hukum yang menangani perkara Tindak Pidana Korupsi; (c) Hak menyampaikan saran dan pendapat secara bertanggung jawab kepada penegak hukum yang menangani perkara Tindak Pidana Korupsi; (d) Hak untuk memperoleh jawaban atas pertanyaan tentang laporannya yang diberikan kepada penegak hukum dalam waktu paling lama 30 (tiga puluh) hari; (e) Hak untuk memperoleh perlindungan hukum dalam hal: Melaksanakan haknya sebagaimana dimaksud dalam huruf a,b, dan c; dan diminta hadir dalam proses penyelidikan, penyidikan dan di sidang pengadilan sebagai saksi pelapor, saksi atau saksi ahli, sesuai dengan ketentuan peraturan perundang-undangan yang berlaku.

Perlindungan hukum yang dimaksud adalah terhadap pelapor yang menyampaikan informasi, saran dan/atau pendapat adanya dugaan telah terjadi tindak pidana korupsi sebagaimana telah dijelaskan diatas, dimaksudkan untuk memberikan rasa aman bagi pelapor yang dilaksanakan sesuai dengan ketentuan peraturan perundang-undangan. Dalam hal memberikan rasa aman terhadap pelapor, penegak hukum atau KPK wajib merahasiakan kemungkinan dapat diketahuinya identitas pelapor atau isi informasi, saran, atau pendapat yang disampaikan. Apabila diperlukan, atas permintaan pelapor, penegak hukum atau KPK dapat memberikan pengamanan fisik terhadap pelapor maupun keluarganya
KPK sebagai lembaga $\mathrm{Ad} \mathrm{Hoc}$, sejak dibentuk tahun 2002 berdasarkan Undang-Undang Republik Indonesia Nomor 30 Tahun 2002 tentang Komisi Pemberantasan Tindak Pidana Korupsi (Lembaran Negara Republik Indonesia Tahun 2002 Nomor 137, Tambahan Lembaran Negara Republik Indonesia Nomor 4250) telah mengembalikan kepercayaan masyarakat terhadap lembaga negara yang khusus menangani tindak pidana korupsi di Indonesia (Wardojo \& Purwoleksono, 2018). Dalam rangka mengoptimalkan peran serta masyarakat dalam upaya pencegahan dan pemberantasan Tindak Pidana Korupsi, pejabat yang berwenang atau KPK diwajibkan untuk memberikan jawaban atau keterangan berdasarkan laporan dari masyarakat sesuai dengan tugas dan fungsinya masing-masing. Kewajiban tersebut diimbangi pula dengan kesempatan pejabat yang berwenang atau KPK menggunakan hak jawab berupa bantahan terhadap informasi yang tidak benar dari masyarakat.

Disamping itu, untuk memberi motivasi yang tinggi kepada masyarakat, maka perlu diadakan berupa pemberian penghargaan kepada masyarakat yang berjasa terhadap upaya pencegahan dan pemberantasan Tindak Pidana Korupsi berupa piagam atau premi. Maka dari itulah dikeluarkanlah Peraturan Pemerintah Republik Indonesia Nomor 43 Tahun 2018 Tentang Tata cara Pelaksanaan Peran Serta Masyarakat dan Pemberian Penghargaan dalam Pencegahan dan 
Pemberantasan Tindak Pidana Korupsi, diatur secara rinci dapat dijabarkan, sebagai berikut:

\section{Pasal 5}

"Masyarakat dapat memberikan informasi mengenai adanya dugaan telah teg'adi tindak pidana korupsi kepada:

a. pejabat yang berwenang pada badan publik; dan/atau

b. Penegak Hukum".

\section{Pasal 7}

(1). "Pemberian informasi kepada Penegak Hukum sebaga is16114 dimaksud dalam Pasal 5 huruf b dilakukan dengan membuat laporan".

(2) "Laporan sebagaimana dimaksud pada ayat (I) dapat disampaikan secara lisan atau tertulis baik melalui media elektronik maupun nonelektronik".

(3) "Dalam hal laporan sebagaimana dimaksud pada ayat (2) disampaikan secara lisan, Penegak Hukum atau petugas yang berwenang wajib mencatat laporan secara tertulis".

(4) "Laporan sebagaimana dimaksud pada ayat (3) wajib ditandatangani Pelapor dan Penegak Hukum atau petugas yang berwenang".

\section{Pasal 8}

(1) "Laporan mengenai dugaan telah terjadi tindak pidana korupsi aebagaimana dimaksud dalam Pasal 7 paling sedikit memuat: a. identitas Pelapor; dan $\mathrm{b}$. uraian mengenai fakta tentang dugaan telah tedadi tindak pidana korupsi"

(2) "Dalam menyampaikan laporan sebagaimana dimaksud pada ayat (I) harus disertai dengan dokumen pendukung paling sedikit: a. fotokopi kartu tanda penduduk atau identitas diri yang lain; dan b. dokumen atau keterangan yang terkait dengan dugaan tindak pidana korupsi yang dilaporkan".

\section{Pasal 9}

(1) "Penegak Hukum wajib melakukan pemeriksaan terhadap laporan sebagaimana dimaksud dalam Pasal 8 secara administratif dan substantif".
(2) "Pemeriksaan sebagaimana dimaksud pada ayat (1) dilakukan dalam waktu 30 (Tiga Puluh) hari kerja terhitung sejak tanggal laporan diterima".

(3) "Dalam proses pemeriksaan substantif sebagaimana dimaksud pada ayat (I), Penegak Hukum dapat meminta keterangan dari Pelapor".

(4) "Pemberian keterangan oleh Pelapor sebagaimana dimaksud pada ayat (3) dapat disampaikan secara lisan dan/atau tertulis. (5) Dalam hal Pelapor tidak memberikan keterangan sebagaimana dimaksud pada ayat (3), tindak lanjut laporan ditentukan oleh Penegak Hukum".

Pasal 10

(I) "Pelapor berhak mengajukan pertanyaan tentang laporannya yang diberikan kepada Penegak Hukum sebagaimana dimaksud dalam Pasal 7 ayat (1)".

(2) "Penegak Hukum wajib memberikan jawaban atas pertanyaan tentang laporan sebagaimana dimaksud pada ayat (1) dalam jangka waktu paling lambat 30 (tiga puluh) hari keq'a terhitung sejak tanggal pertanyaan diajukan".

Adanya pengaturan peran serta masyarakat dalam upaya pencegahan tindak pidana korupsi tersebut diperlukan suatu langkah konkrit. Salah satu upaya pemberantasan tindak pidana korupsi adalah peran serta masyarakat melalui suatu Gerakan Anti Korupsi di Masyarakat. Gerakan anti korupsi tersebut harus didukung oleh semua lapisan masyarakat seperti mahasiswa, LSM, dan pers baik media cetak maupun elektronik, tokohtokoh masyarakat, pemuda, dan organisasi massa lainnya (Arsyad, 2010). Gerakan ini adalah upaya bersama yang bertujuan untuk menumbuhkan paya budaya Anti Korupsi di Masyarakat. Dengan tumbuhnya budaya Anti Korupsi di masyarakat 
diharapkan dapat mencegah munculnya perilaku koruptif.

Gerakan anti korupsi pada dasarnya adalah upaya bersama seluruh konsumen bangsa dan mencegah peluang terjadinya perilaku koruptif. Dengan kata lain gerakan anti korupsi adalah suatu gerakan yang memperbaiki individu (manusia) dan sistem mencegah terjadinya perilaku koruptif. diyakini bahwa upaya perbaikan sistem (sistem hukum dan kelembagaan serta norma) dan perbaikan perilaku manusia (moral dan kesejahteraan) dapat menghilangkan atau setidaknya memperkecil peluang bagi berkembangnya korupsi di Negara ini (Nugraheni, 2017). Upaya perbaikan perilaku manusia dimulai dari hal-hal kecil dengan menanamkan nilai-nilai, baik dari segi nilai kejujuran, kepedulian, tanggung jawab, kerja keras, kesederhanaan, keberanian dan keadilan yang mendukung terciptanya perilaku anti korupsi.

Pembenahan budaya hukum merupakan aspek signifikan yang melihat bagaimana masyarakat menganggap ketentuan-ketentuan sebagai civic minded (berpihak pada kepentingan masyarakat) sehingga masyarakat akan selalu taat dan sadar akan pentingnya hukum sebagai suatu regulasi umum (Manegeng, 2014). Jadi intinya Pemberantasan korupsi pada dasarnya bukan hanya tugas sejumlah lembaga negara atau penegak hukum saja, tetapi juga perlu peran serta masyarakat. Peran serta masyarakat yang diperlukan tidak hanya terbatas pada pengaduan dan laporan terkait tindak pidana korupsi, namun peran serta masyarakat yang baik harus terus dibangun salah satunya melalui pendidikan. Masyarakat perlu pemahaman terkait nilai-nilai integritas dan penanaman semangat antikorupsi dalam dirinya serta pengetahuan mengenai bentukbentuk tindak pidana korupsi yang ada. Sehingga apabila mereka telah mengerti dan memahami, mereka bisa melakukan tindakan preventif terhadap tindak pidana korupsi yang akan terjadi. Pencerminan kehendak masyarakat yang tidak mentolerir tindak pidana korupsi juga harus ditumbuhkan sehingga akhirnya masyarakat dapat berperan sebagai kekuatan yang mengawasi perilaku individu khususnya warga masyarakat dan instansi pemerintah dalam mekanisme administrasi negara (Ardhyanasari, 2017).

Melihat fakta berbagai fenomena dari dampak korupsi yang demikian dahsyat, dan sangat merugikan masyarakat, maka saatnya masyarakat sadar dan bertindak serta diperlukan sebuah keseriusan dalam penegakan hukum guna pemberantasan tindak pidana korupsi. Berkaitan dengan penegakan hukum Barda Nawawi Arief berpendapat bahwa Penegakan hukum adalah menegakkan nilai-nilai kebenaran dan keadilan. Disini berarti bahwa penegak hukum dipercaya oleh masyarakat untuk menegakkan nilai-nilai kebenaran dan keadilan yang terkandung di dalam hukum. Namun demikian dalam penegakan hukum itu terdapat sisi yang penting yaitu peran serta 
masyarakat, yang kemudian disebut sebagai kontrol sosial (Ridwan, 2014).

Korupsi yang terjadi di negara kita ini kurangnya kontrol sosial, baik kontrol sosial dari kepolisian maupun masyarakat atau lingkungan sosial yang membuatnya demikian. Akibat dari hal ini semakin membuat perilaku koruptif yang menjadi cikal bakal korupsi itu semakin berkembang. Kontrol sosial yang dimaksud disini adalah sebuah tindakan untuk mengawasi perilaku menyimpang dalam hal ini adalah perilaku koruptif. Kontrol sosial juga dapat dikatakan proses yang direncanakan maupun yang tidak direncanakan untuk mendidik, mengajak atau bahkan memaksa para warga masyarakat agar menyesuaikan diri dengan kebiasaan dan nilai kehidupan masyarakat yang bersangkutan. Ketika dalam masyarakat sudah ditekankan demikian, maka perilaku korupsi ini bisa dicegah sejak dini. Itulah sebabnya Pentingnya Peran Serta Masyarakat dalam Pemberantasan Korupsi.

Sebagaimana dikatakan diawal bahwa masyarakat dalam melakukan kewajibannya di sini merasa masa bodoh. Masyarakat hanya membebankan tugas pemberantasan Tindak Pidana Korupsi ini kepada penegak hukum, tetapi belakangan menyebutkan banyaknya laporan Tindak Pidana Korupsi oleh masyarakat. Ketua Komisi Pemberantasan Korupsi (KPK) Agus Rahardjo menyatakan pentingnya peran masyarakat dalam pemberantasan korupsi. Tahun ke tahun, semakin banyak laporan dari masyarakat tentang tindak pidana korupsi yang dilakukan penyelenggara atau pejabat negara. Meningkatnya operasi tangkap tangan (OTT) merupakan salah satunya bukti peran serta masyarakat. Dalam sebuah wawancara Agus di Kementerian Pendidikan dan Kebudayaaan menyatakan sebetulnya, meningkatnya OTT hari ini juga dasarnya laporan masyarakat. Tapi dalam waktu yang bersamaan kita mengawasi dan mendampingi. Agus mengapresiasi keinginan masyarakat dalam mengawasi segala bentuk Tindak Pidana Korupsi (Liputan 6, 2018). Ini membuktikan bahwa kesadaran masyarakat dalam kasus Tindak Pidana Korupsi semakin meningkat. Hal tersebut menjadi wajar, karena Tindak Pidana Korupsi merupakan kejahatan sosial dan yang paling dirugikan adalah masyarakat itu sendiri.

\section{SIMPULAN}

Penutup dari artikel ini, dapat dikemukakan simpulan : pertama, peran masyarakat dalam upaya pencegahan dan pemberantasan korupsi sangat diperlukan dalam pemberantasan Tindak Pidana Korupsi. Paling tidak, masyarakat harus ikut ambil bagian karena dua hal yakni masyarakat sebagai korban dan masyarakat sebagai komponen negara. Kedua, bentuk peran serta masyaraka, yakni dengan mempedomani peran serta masyarakat dalam upaya pencegahan dan pemberantasan korupsi sebagaimana telah diatur dalam perundang-undangan, dengan melakukan kontrol sosial yang direncanakan maupun yang 
tidak direncanakan untuk mendidik, mengajak atau bahkan memaksa para warga masyarakat agar menyesuaikan diri dengan kebiasaan dan nilai kehidupan masyarakat yang bersangkutan. Ketika dalam masyarakat sudah ditekankan demikian, maka perilaku korupsi ini bisa dicegah sejak dini.

\section{DAFTAR PUSTAKA}

\section{BUKU}

Sutedi, A. (2015). Buku Pintar Perseroan Terbatas, cet. I. Jakarta: Raih Asa Sukses.

Hamzah, A. (1999). Korupsi di Indonesia, Masalah dan Pemecahannya. Jakarta: Gramedia.

Nugraheni, H. dkk, (2017). Mahasiswa Pelopor

Gerakan Anti Korupsi, cet. 1. Semarang: Politekkes Kemenkes.

Surachmin \& Cahaya, Suhandi. (2013). Strategi dan Teknik Korupsi: Mengetahui Untuk Mencegah. Jakarta: Sinar Grafika.

\section{J URNAL}

Arsyad, A. (2010). Membudayakan Gerakan Anti Korupsi Dalam Rangka Penanggulangan Korupsi Di Indonesia. INOVATIF J urnal IImu Hukum, Vol.2 (No.2), pp.45-54, p.52.

Basri. (2017). Penegakan Hukum Kejahatan Korupsi Melalui Pendekatan Transendental. J urnal Varia J usticia, Vol. 13,(No.2), pp.8292, p.82.

Garnasih, Y. (2009). Paradigma Baru Dalam Pengaturan Anti Korupsi Di Indonesia Dikaitkan Dengan Uncac 2003. Jurnal
Hukum Prioris, Vol.2 (No.3), pp.161-174, p.161.

Kurniawan, T. (2009). Peranan Akuntabilitas Publik dan Partisipasi Masyarakat dalam Pemberantasan Korupsi di Pemerintahan, Bisnis \& Birokrasi. Jurnal Ilmu Administrasi dan Organisasi, Vol.16 (No.2), pp.116-121, p117.

Putriyana, Nia., \& Puspita, Shintiya Dwi. (2014). Tanggung Jawab Hukum Dalam Konteks Perbuatan Melawan Hukum Terhadap Tindak Pidana Korupsi. J urnal Arena Hukum, Vol.7, (No.3), pp.431-457, p.435.

Mahfud, A. (2017). Empowernment and AntiCorruption NGO's. International J ournal of Business, Economics and Law, Vol. 14. (Issue 4. December), p.118-123.

Manegeng, Rebeca V. (2014). Penghalang Dan

Pencegahan Terhadap Pemberantasan Korupsi Di Indonesia. Lex et Societatis, Vol. 2, (No.8), pp.50-59.

Pohan, S. (2014). Perbandingan Lembaga Anti Korupsi Di Indonesia Dan Beberapa Negara Dunia. J urnal J ustitia, Vol.1 (No.3), pp.271303, p.271.

Ridwan. (2012). Kebijakan Formulasi Hukum Pidana Dalam Penanggulangan Tindak Pidana Korupsi, J urnal Law Reform, Vol.8, (No.1), pp.78-97, p.79.

Ridwan. (2014). Upaya Pencegahan Tindak Pidana Korupsi Melalui Peran Serta Masyarakat, 
Law Reform

Volume 15, Nomor 1, Tahun 2019

Kanun Jurnal IImu Hukum, Vol.16, (No.3), pp.385-299, p.393.

Rohrohmana, B. (2017). Penerapan Ajaran Turut Serta Dalam Tindak Pidana Korupsi. J urnal Yuridika, Vol.32 (No.2), pp.210-27, p.210.

Santoso, Listiyono., \& Meyrasyawati, Dewi. (2015).

Model Strategi Kebudayaan Dalam

Pemberantasan Korupsi. Jurnal Review

Politik, Vol. 05, (No. 01), p.22-45.

Sukmareni. (2018). Penegakan Hukum terhadap

Tindak Pidana Korupsi menurut Sistem

Peradilan Pidana Indonesia. Pagaruyung

Law Journal, Vol.1, (No.2), pp.159-179, p.160.

Sulastri, I. (2012). Perlunya Menanamkan Budaya Anti Korupsi Dalam Diri Anak Sejak Usia Dini, Jurnal Mimbar Hukum, Vol.24, (No.1), pp.98-109, p.99.

Sumarni. (2015). Peran Lembaga Swadaya Dalam

Pencegahan, Pengendalian, dan

Penanganan Kasus Korupsi di Kota

Samarinda. el ournal Sosiologi. Universitas

Mulawarman, Vol 3, (No. 2), p.111-123.

Thalib, Hambali., Ramadhan, Ahmad., \& Djanggih, Hardianto. (2017). The Corruption Investigation In The Regional Police of Riau Islands, Indonesia. Rechtsidee, Vol.4,(No.1), pp.71-86, p.81.

Putra, I Made Walesa., Widhiyaastuti, I Gusti Agung Ayu Dike., Putra, I Putu Rasmasi Arsha. (2018). Peran Serta Masyarakat Dalam Pencegahan Tindak Pidana Korupsi
Program Studi Magister Ilmu Hukum Fakultas Hukum Universitas Diponegoro

Pengelolaan Keuangan Dana Desa. Studi Di Desa Cau Belayu. Kecamatan Marga, Kabupaten Tabanan, Propinsi Bali. Jurnal Acta Comitas; Jurnal Hukum Kenotariatan. Vol. 3, (No.1), p.1-16.

Waluyo. B. (2014). Optimalisasi Pemberantasan Korupsi Di Indonesia. Jurnal Yuridis, Vol.1 (No.2), pp.169-182.

Wardojo, Mellysa Febriani., \& Purwoleksono, Didik Endro. (2018). Kedudukan Komisi Pemberantasan Korupsi Sebagai Lembaga Negara. J urnal Hukum Legal Standing, Vol.2, (No.1), pp.73-83, p.73

Widyastuti, Anastasia R. (2015). Disfungsionalisasi

Birokrasi Sebagai Kendala Dalam Pemberantasan Korupsi. Yustisia J urnal IImu Hukum, Vol. 4 (No.3), pp.683-699, p.684

\section{SUMBER ONLINE}

Anugrahadi, A. (2018). Laporan Masyarakat ke KPK Meningkat, OTT pun Semakin Sering. Retrieved from https://www.liputan6.com/ news/read/3469676/laporan-masyarakat-kekpk-meningkat-ott-pun-semakin-sering, diakses tanggal 02 juni 2018.

Matodang, M. (2012). Peran serta Masyarakat Dalam Pemberantasan Korupsi. Retrieved from https://martohaprpm.blogspot.co.id/ 2012/11/peran-serta-masyarakatdalam.html?m=1, diakses tanggal 25 April 2018 pukul 19:39 
Law Reform

Volume 15, Nomor 1, Tahun 2019

Ardhyanasari, A. (2017). Masyarakat Melawan Tindak Pidana Korupsi. Retrieved from https://acch.kpk.go.id/id/component/content/a rticle?id, diakses tanggal 02 juni 2018

\section{PERATURAN PERUNDANG - UNDANGAN}

Undang-Undang Nomor 8 Tahun 1981 Tentang Kitab Undang-Undang Hukum Acara Pidana (KUHP)

Undang-Undang Nomor 20 Tahun 2001 Tentang Perubahan Undang-Undang Nomor 31 Tahun 1999 Tentang Pemberantasan Tindak Pidana Korupsi

Undang-Undang Republik Indonesia Nomor 30 Tahun 2002 Tentang Komisi Pemberantasan Tindak Pidana Korupsi

Peraturan Pemerintah Republik Indonesia Nomor 43 Tahun 2018 Tentang Tata Cara Pelaksanaan Peran Serta Masyarakat Dan Pemberian Penghargaan Dalam Pencegahan Dan Pemberantasan Tindak Pidana Korupsi
Program Studi Magister Ilmu Hukum Fakultas Hukum Universitas Diponegoro 